\title{
Lysosomes and the connective tissue diseases
}

\author{
LUCILLE BITENSKY \\ From the Cellular Biology Division, Kennedy Institute of Rheumatology, Bute Gardens, London
}

Lysosomes are small intracellular organelles present in most or all cells of animals of widely different evolutionary development. In general their diameter may vary from 0.2 to $0.5 \mu \mathrm{m}$ so that they overlap the dimensions of mitochondria. In the original differential centrifugation studies they were isolated as the 'light mitochondrial' fraction. It is difficult to give an exact size to these organelles because the term 'lysosome' covers a wide range of structures from the small primary lysosomes budded off from the Golgi apparatus, to secondary lysosomes caused by the fusion of primary lysosomes with endocytotic vacuoles, to complex fusion-structures such as heterolysosomes and autophagic vacuoles. Indeed, de Duve (1969) suggested that lysosomes are only a part of the intracellular vacuolar system. Consequently the term 'lysosome' includes granules of various sizes, specific densities, and enzymatic content.

Possibly these structures have different complements of enzymes in the various tissues of the same animal. The lysosomes of polymorphonuclear cells, the azurophil, and possibly the specific granules (Goldstein, 1974) are peculiar in both their relatively great size and enzymic complement. Seemingly, however, the main cellular content of hydrolytic enzymes, particularly those acting optimally at an acidic $\mathrm{pH}$, is within the lysosomes and is one of the characterising features of these organelles. They may be defined as small intracellular organelles that contain acid hydrolases bounded by a semi-permeable membrane which is said to control the latency of the intralysosomal enzymes and to allow the organelles to behave as osmometers (de Duve, 1959). By electron microscopy they are seen to be bounded by a single membrane (Daems et al., 1969; Schellens et al., 1977).

Lysosomes can be seen when living cells are examined by phase-contrast microscopy, when their greater refractility distinguishes them from the smaller mitochondria or chondriosomes. Indeed, it is now apparent that the lipochondria of the older microscopists probably correspond to lysosomes (Lane, 1968; Munro et al., 1964). Such bodies were seen to congregate around the food vacuole in amoebae shortly after the uptake of food. Cor- respondingly, in phagocytic cells primary lysosomes become attached to endocytic vacuoles and release their hydrolytic enzymes into these vacuoles, digesting the endocytosed matter (Cohn and Fedorko, 1969).

\section{Methods for studying lysosomes}

BIOCHEMICAL

The term 'lysosome' was coined by de Duve (de Duve et al., 1955; de Duve, 1969) for particles isolated by homogenisation and differential centrifugation that contained acid hydrolases in a latent form. The latency of the enzymic activities was the most surprising feature of this organelle. Now these structures are usually separated from mitochondria by recentrifuging the crude 'mitochondrial' pellet to equilibrium in a medium that has a gradient of different specific gravities. The lysosomes equilibrate at a specific gravity of about 1.22 whereas the mitochondria accumulate at a specific gravity of about $1 \cdot 19$ (Beaufay, 1969). Occasionally the specific gravity of the lysosomes is deliberately altered by using their ability to concentrate material of low density such as Triton WR-1339 or material of high density such as Dextran 500, iron, or gold (Dean and Barrett, 1976; Dean, 1977b).

If lysosomes were completely stable possibly the activities of none of their characteristic enzymes could be demonstrated biochemically because all would be sequestered behind the semi-permeable membrane of the organelle. Treatment with acetate at pH 5.0 at $37^{\circ} \mathrm{C}$, or more crudely with a surfactant such as Triton X-100, modifies or otherwise disrupts the lysosomal membrane and releases the enzymes, which then express their full biochemical activity. When there is no 'free' activity, so that the activity of the intralysosomal enzymes is totally latent, the membrane is considered fully stable. This type of finding led to the idea that these organelles were 'suicide particles' by analogy with the suicide pastilles that could safely be held in the mouth until the casing was broken. However, it was then found that in different physiological and pathological conditions more or less of the enzymic activities were present in the fluid in which the purified lyso- 
somal fraction was isolated. This gave rise to many studies (for example, de Duve, 1959; Peters et al., 1975 ) in which the 'free' activity was measured separately from that activity which still remained latent, or bound, within the organelles and which could be measured only after the particles had been physically or chemically disrupted. This 'free-tobound' ratio seemed to relate to physiological or pathological activity in the cells.

\section{ELECTRON MICROSCOPY}

Lysosomes and related structures are recognised by the characteristic single outer membrane bounding a structure that may be electron-dense and contains acid hydrolase activity. The application of electron microscopy to the study of lysosomes has been fully reviewed by Daems (Daems et al., 1969; Schellens et al., 1977)

\section{CYTOCHEMISTRY}

Lysosomes can be recognised by their concentration of acridine orange so that they appear as vivid red granules when viewed by fluorescence microscopy (Robbins and Marcus, 1963; Allison and Young, 1969). They can usually be stained histochemically by a suitable method for acid phosphatase activity (Holt, 1959; Bitensky, 1963a, b) because the lysosomes of most but not of all cells contain active acid phosphatases. The presence of lysosomal enzymes, in characteristic particles, can also be visualised by immunohistochemical methods (Weston and Poole, 1973).

Quantitative cytochemical methods applicable to the activity of many characteristically lysosomal enzymes are now well established (Bitensky and Chayen, 1977). Two of these techniques allow the assessment of 'freely manifest' and of 'bound', or latent, activity, approximating to the free-to-bound ratios used by biochemists. These cytochemical techniques are considerably more sensitive than the biochemical tests for assessing the function of the lysosomal membranes. For example, they have shown that thyrotrophin, acting on thyroid follicle cells, increases the instability of the lysosomal membranes as a prelude to lysosomal involvement in the production of thyroid hormones.

The cytochemical bioassay of thyrotrophin (Bitensky et al., 1974a), 10000 times more sensitive than the radioimmunoassay, is now the microbioassay recommended by the World Health Organization. The cytochemical ratio of freely available to total activity is altered in many pathological states and during physiological conditions which apparently depend on lysosomal intervention (Bitensky, 1963b; Bitensky et al., 1973). One of the advantages of cytochemical investigations is that the lysosomal activity in histologically identified cells can be measured in individual cells by microdensitometry.

\section{Contents of lysosomes and role in inflammation}

Lysosomes in different cell-types contain different enzymes and bioactive molecules, and possibly the lysosomes of any one cell type are not homogeneous. Nevertheless, the lysosomes of most if not all cells contain an array of hydrolytic enzymes including those that will hydrolyse proteins, nucleic acids, polysaccharides, and phospholipids. The $\mathrm{pH}$ optima of all these enzymes, with a few exceptions, are in the acidic range. Barrett and Dean (1976; Barrett and Heath, 1977) have listed all the lysosomal enzymes that have been encountered. The possible role of the proteinases in the degradation of the protein matrix of cartilage in rheumatoid arthritis has been much studied (Dingle, 1962; Weissmann, 1966). The phospholipases are thought to have a potential function in the liberation of unsaturated fatty acids that initiates the formation of prostaglandins (Anderson et al., 1971; Zurier, 1974). Prostaglandins alone can cause resorption of bone (Robinson et al., 1975) and their production can be blocked at a very early stage by glucocorticoids (Kantrowitz et al., 1975) which influence lysosomal function (see later).

Lysosomes of many types of cell also contain amino-acid arylamidases capable of generating bradykinin or other inflammatory amines from their inactive precursors (Hopsu-Havu et al., 1966). Apart from such enzymes lysosomes of polymorphonuclear leucocytes contain a number of inflammatory mediators (Goldstein, 1974) including cationic proteins (Janoff and Zweifach, 1964), an activator of plasminogen (Lack and Ali, 1964), a protease that causes changes in the permeability of capillaries (Movat et al., 1964; Uriuhara et al., 1965), as well as haemolysins (Desai and Tappel, 1965). Thus, not surprisingly, when the contents of lysosomes isolated biochemically were injected under the skin or into joints (Weissmann et al., 1969) they proved highly inflammatory. Repeated intra-articular injection of lysates of lysosomes isolated from rabbit leucocytes produced hypertrophy and hyperplasia of the cells lining the synovium, round cell infiltration of the synovium close to blood vessels, the formation of a pannus, and erosion of cartilage (Weissmann et al., 1969; Page-Thomas, 1969). Moreover, the fact that many anti-inflammatory agents appreciably stabilise lysosomal membranes (Weissmann, 1968, 1969; Chayen et al., 1972; Bitensky et al., 1974b) also indicates a strong lysosomal component in inflammation. 


\section{Intracellular digestion}

There is now a wealth of information about the intracellular digestion, mediated by lysosomes, of material endocytosed by cells (Dean and Barrett, 1976). There is also clear evidence from electron microscopy that lysosomes participate in the intracellular digestion of parts of the cell such as mitochondria. This process, known as autophagy, is related to the digestion of secretory granules (crinophagy) - seen, for example, in the parathyroid and pituitary glands-which apparently regulates the amount of hormone available for secretion. Crinophagy can be induced in the appropriate cells in the anterior lobe of the pituitary gland if secretion of the trophic hormone is blocked (Farquhar, 1969). However, autophagy and possibly crinophagy may represent pathological roles of the intracellular lysosomal digestive system.

Over and above these morphologically identifiable processes, lysosomes in normal cells are probably concerned with the regular degradation of cellular components and the turnover of cellular proteins. Thus the normal rate of degradation of intracellular proteins in the liver is retarded by causing a specific inhibitor of carboxyproteinases, supplied in liposomes, to be incorporated into liver lysosomes (Dean, 1975). Further evidence of lysosomal participation in the normal turnover of cellular proteins is given by Dean (1977a; La Badie et al., 1976). The indirect evidence that lysosomes are concerned in the turnover of other chemical components of cells comes from the study of inborn errors of metabolism (see later; also M. F. Dean (Dean, 1978) at page 120).

\section{Extracellular digestion}

The extracellular release of lysosomal enzymes into the lacunar space has been implicated in the destruction of bone by osteoclasts (Vaes, 1969). There is evidence that lysosomal cathepsin $D$ released from cells participates in the early stages of the breakdown of connective tissues (Dingle, 1971). Dingle (1968) suggested that the release of lysosomal enzymes from cells could be as packages released by exocytosis.

The earlier work of Fell and coworkers (Fell and Thomas, 1960) is still the clearest evidence that lysosomal enzymes released from living cells can degrade cartilage and other connective tissue. In particular, studies on cells in tissue or organ culture have shown that addition of vitamin A (which labilises lysosomes) or of non-digestible material (which accumulates within lysosomes) results in the release into the culture medium of lysosomal enzymes and in the loss of metachromasy in the cartilage (Fell and Dingle, 1963; Dingle et al., 1969; Dingle, 1969).
Other, more circumstantial, evidence will be discussed later. Nevertheless, these studies indicated that degradation of the matrix of connective tissue could result from the extracellular release of lysosomal enzymes from still-viable cells.

\section{Nature of lysosomal enzymes}

\section{INTRALYSOSOMAL pH}

There has been some concern over the fact that most of the enzymes located within lysosomes act optimally at $\mathrm{pH}$ values around $\mathrm{pH} 5$ or even lower, and that some are totally inactive at what is considered to be the 'physiological pH'-namely, about pH 7.

Several attempts have been made to explain how the $\mathrm{pH}$ within these organelles can be so different from that of their environment. Some have adduced evidence for an active proton pump (de Duve $e t$ al., 1974; Mego, 1973) to explain why the measurable intralysosomal $\mathrm{pH}$ is appreciably lower than the $\mathrm{pH}$ of the surrounding medium. Goldman (1976) found it to be 1.6 units of $\mathrm{pH}$ lower; Reijngoud and Tager (1973) found it to increase from $\mathrm{pH} 4.9$ to 6.9 as the $\mathrm{pH}$ of the external medium was raised from 5.0 to $8 \cdot 5$. Moreover, Koenig (1974) showed that lipoproteins make up about half of the total protein complement of lysosomes isolated from rat liver and kidney.

The influence of these acidic, ionisable phosphate moieties could play some part in maintaining a relatively acidic hydrogen-ion activity (see below) at the active sites of the intralysosomal enzymes. Dean and Barrett (1976) considered that such fixed anions in the interior of the organelles could be sufficient to account for the maintenance of the acidic intraorganelle $\mathrm{pH}$ that has been recorded (Goldman, 1976) without recourse to active proton pumps. Among the fixed anions they listed were sialic acid on the inside of the membrane, acidic lipoproteins and phospholipids, and an excess of amino-acids produced by hydrolysis of peptide bonds.

pH OF EXTRACELLULAR DIGESTION

Many workers are disquieted by the fact that lysosomal enzymes act optimally at acidic $\mathrm{pH}$ values while the digestion of extracellular matrix occurs, ostensibly, at physiological $\mathrm{pH}$ values-namely, around pH 7.0. Because purified cathepsin D had no detectable action on a protein-polysaccharide complex or proteoglycan subunit at physiological $\mathrm{pH}$, Woessner (1973) concluded that it and, presumably, other cathepsins with acidic optimal activities were unlikely to have any significant effect on the matrix of cartilage at $\mathrm{pH}$ values greater than $\mathrm{pH}$ 6.0. Any degradation of cartilage must therefore be due to the influence of neutral proteases. Such proteases 
have been found in the granules of polymorphonuclear leucocytes (Goldstein, 1974) and in other cells. Lysosomal carboxypeptidase B and cathepsin $\mathrm{C}$ have been shown to have $\mathrm{pH}$ optima of 6.2 and 5-6 respectively (Barrett and Heath, 1977).

Some lysosomal endopeptidases, such as acrosin (pH optimum: 8 ) and cathepsin $\mathrm{G}$ (pH optimum: 7.5), act optimally at around neutral $\mathrm{pH}$, as do some other enzymes such as aspartyl glucosyl aminase (E.C. 3.5.1.26) which hydrolyses the amide link in aspartamido-( $\mathrm{N}$-acetyl-) glucosamine, and which may be relevant to the breakdown of cartilagematrix (Barrett and Heath, 1977). Furthermore, even such endopeptidases as cathepsin $\mathbf{B}$, which acts optimally at $\mathrm{pH}$ values of between $3 \cdot 5-6 \cdot 0$, may still have significant activity at higher $\mathrm{pH}$ values, even at $\mathrm{pH} 7 \cdot 0$.

The lowest mean $\mathrm{pH}$ of sterile inflammatory exudates has been measured as 7.049 (Edlow and Shelden, 1971), leading Goldstein (1974) to conclude that the $\mathrm{pH}$ was far above the range at which acid cathepsins could be active. Similarly the $\mathrm{pH}$ of fluid from rheumatoid joints was 7·1-7.28 (Barnett et al., 1961 ; Cummings and Nordby, 1966). However, these arguments are somewhat academic. There is sufficient neutral lysosomal protease activity to account for degradation of tissue matrix at neutral $\mathrm{pH}$, and polymorphonuclear leucocytes, when involved, contain an array of neutral hydrolytic lysosomal enzymes (Barrett and Heath, 1977). Moreover, the whole argument is based on the pHnamely the hydrogen-ion concentration in solution -which operates when solubilised enzymes act on their substrate in solution.

Small (1954) emphasised that at surfaces we are concerned not with $\mathrm{pH}$ but with hydrogen-ion activity. McLaren and Packer (1970) reviewed the whole question of how $\mathrm{pH}$ optima can be modified when the enzyme becomes bound to a solid matrix or when a soluble enzyme acts to digest a solid matrix, as it must when digesting extracellular connective tissue components. Several examples are now known of enzymes, such as chymotrypsin or trypsin, whose $\mathrm{pH}$ optimum may be changed as much as $2 \mathrm{pH}$ units depending on whether they act in solution or attached to a solid matrix (McLaren and Packer, 1970).

Dean and Barrett (1976) reviewed work on enzymes linked to insoluble model membranes in which extensive changes in the pH optima and even enzymatic characteristics have been recorded. They gave as one example a lysosomal proteolytic activity that acts optimally at pH 6.5 when bound to a membrane but at $\mathrm{pH} 4.5$ when solubilised. It is by no means inconceivable that isolated and purified lysosomal enzymes which act optimally at an acidic
$\mathrm{pH}$ of, for example, 4.5 may in fact act optimally close to neutrality when adsorbed on to extracellular connective-tissue components or even when present within the matrix of the lysosome. A typical example of the former is given by Quarles and Dawson (1969). They studied the action of isolated phospholipase $\mathbf{D}$ acting on micelles of phospholipids and showed that the pH optimum could be shifted $1.5 \mathrm{pH}$ units towards neutrality, depending on the nature of the micelles. They pointed out that the $\mathrm{pH}$ in the bulk phase $\left(\mathrm{pH}_{\mathrm{B}}\right)$ was related to the $\mathrm{pH}$ in the surface phase $\left(\mathrm{pH}_{\mathrm{s}}\right)$ adjacent to a negatively charged interface by an equation derived from the Boltzmann equation:

$$
\mathrm{pH}_{\mathrm{S}}=\mathrm{pH}_{\mathrm{B}}+(\epsilon \psi / 2 \cdot 3 \mathrm{KT})
$$

where $\mathrm{K}$ is the Boltzmann constant, $\mathrm{T}$ is the absolute temperature, $\epsilon$ is the electronic charge, and $\psi$ is the potential of the surface phase (Davies and Rideal, 1961). Although it is difficult to calculate $\psi$ there is every reason to expect a strong shift towards neutrality.

\section{Nature of lysosomal membranes}

Electron microscopy shows that lysosomes are bounded by a single membrane, and biochemical investigations on the osmotic properties of lysosomes (Dean and Barrett, 1976) added weight to the view that these organelles are encased in a semi-permeable membrane. Some biochemical studies indicated that sulphydryl groups in the membrane are important in the labilisation of these membranes by thiols and certain metals (Lucy, 1969) and by vitamin A (Lucy and Lichti, 1969). Lysosomal membranes can be labilised by some steroids and by retinol and stabilised by other steroids(Dean and Barrett, 1976). Dingle and Barrett (1968) isolated a peculiar phospholipid component of lysosomal membranes that may play a significant role in some of the cytochemical tests made on these organelles (Bitensky and Chayen, 1977).

Proof that changes in the permeability of lysosomal membranes, which are sometimes reversible, may play a significant part in cellular physiology and pathology depended on the adequate measurement of lysosomal membrane function. These changes were shown first by cytochemistry (Bitensky, 1963b; Allison and Mallucci, 1964, 1965; Bitensky and Cohen, 1965; Bitensky et al., 1963) but have now been shown biochemically by Peters and Seymour (1976) and by Burton and Lloyd (1976). Both cytochemically and biochemically, the effects measured are estimates of the permeability or stability of the lysosomal membranes. Although there are dissenting voices (Baccino and Zuretti, 1975; Koenig, 1969), 
the weight of evidence favours the concept that reversible changes do occur in the permeability of lysosomal membranes under different physiological and pathological conditions and when tissues are subjected to drugs such as steroids (Weissmann, 1969; Allison, 1968a; Bitensky et al., 1974b) or dimethyl sulphoxide (Misch and Misch, 1975).

\section{Pathogenetic role of lysosomes}

Lysosomes were first thought of as 'suicide capsules'. When they burst they would release their cytolytic enzymes into the cytosol and digest the cell in which they were present. Although there was some evidence that this might occur in morphogenesis (Weber, 1969), it is now clear that this is remarkably rare and occurs only in a few particular situations. One such situation was shown to be the uptake of toxic particles by macrophages (Allison et al., 1966; Allison, 1971). Silica was taken up by these cells, lysosomes fused with the phagosome and released lysosomal enzymes into the so-formed secondary lysosomes. The toxic particles, such as those of silica, reacted with the membranes of the lysosomes (Allison, 1968a, b), allowing the lysosomal enzymes to escape into the cytoplasm. Macrophages that had ingested such particles were killed within 24 hours whereas those that ingested non-toxic particles (such as diamond dust or silica coated with either aluminium or polyvinyl-pyridine- $\mathrm{N}$-oxide), incapable of disrupting the lysosomal membranes, were not killed.

It now seems likely that the common effect of lysosomes is to release their enzymes into the external milieu of the cell. Dingle (1968) suggested that perturbation of the lysosomal membranes allowed the lysosomes to fuse with similarly perturbed regions of the plasma membrane and so to extrude packages of lysosomal enzymes by a form of exocytosis. Lysolecithin, produced locally, could mediate this phenomenon (Lucy, 1970). An alternative mechanism, which might be called 'regurgitation during feeding', has been postulated by Weissmann et al. (1971a, b). This suggests that the phagocytic vacuole in the leucocyte may remain open at the external surface of the cell and that the lysosomes fuse with the inner boundary of such vacuoles and release their enzymes into these vacuoles, which, being still open to the outside medium, allow the loss of lysosomal enzymes into the environment of the cell.

Evidence from electron micrographs is consistent with such a mechansim (Zucker-Franklin and Hirsch, 1964; Henson, 1971). Indeed, there is considerable biochemical evidence for the selective release of lysosomal enzymes from leucocytes and from macrophages (Cardella et al., 1974; Schorlem- mer et al., 1977) when these cells are exposed to a variety of stimuli, including immune complexes. This can occur even in the absence of any signs of loss of viability of the cells, monitored by the release of cytosolic enzymes such as lactate dehydrogenase. A particular example of the release of nine lysosomal enzymes from cells which remain viable is the study by Hösli and Vogt (1977) on fibroblasts grown from patients with cystic fibrosis.

A system of particular interest in inflammation is the activation of complement by lysosomes. Various workers (Goldstein and Weissmann, 1974; Schorlemmer and Allison, 1976) have shown that when mononuclear leucocytes are stimulated by agents that induce chronic inflammation they secrete hydrolytic enzymes. These enzymes degrade connective tissue and interact with the complement system to generate mediators of inflammation. The cleavage products of complement can then further stimulate macrophages (Schorlemmer et al., 1976) to perpetuate the inflammatory response. Many workers have shown that this activation of complement is by the alternative pathway resulting in the cleavage of $\mathrm{C} 3$ and the generation of $\mathrm{C} 3 \mathrm{~b}$, which causes the secretion of hydrolases from these cells. This work, and the concepts arising out of it, have been reviewed by Schorlemmer et al. (1977).

Given that lysosomal enzymes can be exteriorised from the cell, conceivably they could have the following influences.

Firstly, body fluids contain many hydrolytic and degradative enzymes which occur in a latent form, often as a proenzyme or in combination with inhibitors. For example, there is much work on procollagenases and proelastases (Vaes, 1972; Woessner, 1977; Sellers et al., 1977). These can be activated by proteolytic enzymes (Birkedal-Hansen et al., 1976; Dayer, 1976; Eeckhout and Vaes, 1977). Glynn (1977) and Reynolds et al. (1977) suggested that such activation of collagenase, possibly by lysosomal enzymes extruded from still viable cells, could participate in the degradation of cartilage in osteoarthrosis and rheumatoid arthritis. Similarly, cathepsin B can inactivate the circulating $\alpha_{1}$-proteinase inhibitor, allowing proteases, previously latent because of the presence of this inhibitor, to be free to act on connective tissue. (For the possible relationship between this circulating protease inhibitor and emphysema see Galdston et al., 1973; Goldstein, 1974.) Equally lysosomal enzymes can act on kallidin-10 to form bradykinin (Hopsu-Havu et al., 1966; Goldstein, 1974).

Secondly, if the release of lysosomal enzymes were to occur in the synovium or in the joint they could attack the connective tissue matrix, provided that the $\mathrm{pH}$ or hydrogen-ion activity was suitable. 
It could cause a cascade phenomenon of inflammation by the alternative pathway of complement activation; it could influence the permeability of the capillaries; and, by the release of chemotactic substances known to be present in lysosomes (Goldstein, 1974), it could exacerbate the cellular infiltration in the synovium or joint. We have seen that the injection into joints of lysates of lysosomes apparently has all these effects. It is also known that when cells ingest certain substances they release lysosomal enzymes (Dingle et al., 1969). PageThomas (1969) showed that the injection into a joint of disazo dyes or polysaccharides produced an arthritis, apparently due to excessive synthesis of lysosomes and lysosomal enzymes. The ingestion of immune complexes has a similar effect in the secretion of lysosomal enzymes from leucocytes and macrophages (Weissmann et al., 1971b; Cardella et al., 1974).

A different aspect of the extrusion of matter from lysosomes concerns the handling of immune complexes by these organelles. Antigens appear to be taken up into lysosomes by endocytosis and to be 'processed' by them (Weissmann, 1964; Allison, 1968c). The fate of these proteins seems to be determined by the state of the lysosomal membranes. As reviewed by Chayen and Bitensky (1971), the more stable lysosomes (as may occur in polymorphonuclear leucocytes) are said to be capable of more complete digestion of these antigens than are less stable lysosomes, as found in macrophages (Allison, 1968c). Treatment which labilised lysosomal membranes prolonged the 19S antibody response (Weissmann, 1967), implying that the antigen had not been degraded under these conditions (Uhr, 1964). Weissmann $(1964 ; 1966)$ argued that this type of phenomenon could play some part in autoimmunity. The hypothesis requires cells that are undergoing autophagy and endocytosis. If the lysosomal membranes are labile there will be incomplete degradation with retention of antigenicity. The selective release of these incompletely degraded antigens, whether by 'regurgitation,' exocytosis, or any other mechanism, will result in an immune response either to the original cell or to the exogenous immune complex. Similar hypotheses have been propounded by Page-Thomas (1969) and by Hollander (Hollander et al., 1965; Rawson et al., 1965; Restifo et al., 1965). Such hypotheses would account for the chronic nature of rheumatoid arthritis, as discussed by Chayen and Bitensky (1971).

\section{Possible role of lysosomes in certain diseases of connective tissues}

STORAGE DISEASES

Many diseases caused by inborn errors of meta- bolism are now known. They have been reviewed fully by Hers and van Hoof (1973). In many a single specific lysosomal enzyme is absent. The fact that undigested matter accumulates in giant, swollen lysosomes, from which phenomenon the name 'storage diseases' is derived, indicates that lysosomes may well be involved in the normal turnover of these substances. In Tay-Sachs disease there is a deficiency of lysosomal hexosaminidase A which would normally cleave the terminal $\mathrm{N}$-acetyl- $\beta$-D-galactosamine from ganglioside $\mathrm{G}_{\mathbf{M} 2}$. This results in huge lysosomes filled with cytoplasmic membranous bodies presumably of ganglioside material (O'Brien, 1973).

Type II glycogenosis, also called type II glycogenstorage disease or Pompe's disease, is ascribed to a complete defect of $\alpha$-glucosidase; this results in the intralysosomal accumulation of intact glycogen which causes the lysosomes to swell to up to 8 $\mu \mathrm{m}$-diameter (Hers and de Barsy, 1973). Cardiac and skeletal muscle hypertrophy follow. In three of the mucopolysaccharidoses (Hurler's, Hunter's, and Sanfilippo's disease) there may be a complete defect of one of the degradative enzymes-for example, iduronidase (which liberates sulphate ions from dermatan sulphate) in Hurler's disease, sulphatase, or $\beta$-glucuronidase-or partial defects of $\alpha$ - or $\beta$-galactosidases (Hers, 1973). Gaucher's disease, with its hepatosplenomegaly and bone erosion, is associated with a nearly complete defect of glucocerebrosidase ( $\beta$-glucosidase). Gaucher cells are characterised by lysosomes filled with membranebound inclusions (Brady and King, 1973).

These and other lysosomal defects discussed by Hers and van Hoof (1973) indicate how important lysosomes may be in the normal turnover of materials in life, so that defects in their metabolic activity become apparent in these diseases. Surprisingly no genetic disease due to deficiencies of lysosomal proteolytic activity seem to have been recorded. Whether this is because such defects are lethal or because the wide array of proteolytic potency of lysosomes can cover-up the effect of a single deletion is not determined.

\section{GOUT AND CRYSTAL SYNOVITIS}

Long, needle-shaped crystals of monosodium urate monohydrate are found in the fluid from joints during acute attacks of gout (see J. T. Scott (Scott, 1978) at p. 205, and P. A. Dieppe (Dieppe, 1978) at p. 214). It was known in the last century that crystals occurred at the sites of gouty necrosis and that the subcutaneous injection into animals of microcrystals of various urates, xanthine, hypoxanthine, and creatinine-and even of calcium carbonate-provoked acute inflammatory responses 
and the phagocytosis of the crystals by mononuclear and polymorphonuclear leucocytes (Chayen and Bitensky, 1971). These effects were rediscovered by Seegmiller and Howell (1962) and by McCarty (1968). Seegmiller and Howell (1962) suggested that the urate crystallises in tissue or synovial fluid and that the crystals are phagocytosed by leucocytes. They assumed that in this process lactic acid was produced locally. This would lower the $\mathrm{pH}$ and so cause further precipitation of urate from the exudate, which would be in equilibrium with the hyperuricaemic blood. The last step is probably an over-simplification because Watts et al. (1971) found urate crystals in tissues of patients in whom the blood levels of urates were well below saturation.

McCarty (1968) emphasised that inflammation induced by crystals either of urates, as in gout, or of pyrophosphate, as in pseudogout or chondrocalcinosis, depended on the presence of polymorphonuclear leucocytes. Phelps and McCarty (1966) and Chayen and Bitensky (1971), however, reported plenty of urate crystals in some synovial fluids in which very few of these cells could be found. For all that, the general view is that the crystals are phagocytosed by polymorphonuclear leucocytes into an endocytic vacuole. The cells degranulate, injecting their lysosomal enzymes into this vacuole. These enzymes then leak from the cells either by the regurgitation mechanism discussed previously or by some other selective release, very much as when such cells ingest particles of silica (as discussed above). Indeed, there is probably no call to invoke selective release of lysosomal contents from viable cells in this instance and possibly the fluids that contained crystals but very few polymorphonuclear leucocytes could have been sampled at a time when these cells had already disintegrated, before the inflow of fresh cells.

Probably, therefore, the inflammation associated with gout, chondrocalcinosis, and possibly the other calcium phosphate synovitides (Dieppe et al., 1976) is brought about by the lysosomal contents of leucocytes that have ingested these particles. When such crystals are deposited in muscle they do not produce an inflammatory response but may be associated with muscle pain, as in the cases of xanthinuria reported by Chalmers et al. (1969) and possibly when urates of various forms crystallise in the muscle of patients with gout (Watts et al., 1971).

\section{RHEUMATOID ARTHRITIS}

Rheumatoid arthritis is a systemic disease of unknown origin. The earliest joint changes are in the synovium, where the established lesion is characterised by villous enlargement, hyperplasia of the lining cells, infiltration by inflammatory cells, deposi- tion of fibrin interstitially, and the formation of pannus and erosion of cartilage of the joint surface (Lack, 1969). The chronic inflammation and erosion of cartilage point to lysosomal participation. This view is strengthened by the fact that an experimental arthritis can be induced by injecting lysates of lysosomes into the joint (Weissmann et al., 1969) and that it can be produced experimentally (Page-Thomas, 1969) by injecting various substances that interfere with lysosomes, such as those which rupture lysosomes, or disazo dyes which, by inhibiting some lysosomal enzymes, may cause excessive production of other enzymes, as has been found in many of the storage diseases.

If lysosomes participate in the pathogenesis of rheumatoid arthritis it is necessary to identify which cells are involved. In gout there seems little doubt that the lysosomal dysfunction is in the polymorphonuclear leucocytes. These are unlikely to be the source of lysosomal enzymes and inflammatory substances in the rheumatoid joint because, were they the source, the erosive influences would be liberated into the synovial fluid and the erosion of the cartilage would begin uniformly over the whole surface of the cartilage. Ball (1968) has shown that erosion begins at the articular cartilage junction. This location implicates the synovium itself, which originates at this site-at which it also shows its most florid appearance in completely normal joints. Muirden (1972) showed that the severity of joint erosion did not correlate with the degree of inflammatory cell infiltrate in the synovium but with the amount of hyperplasia of the synovial lining cells. Ghadially and Roy (1967) found a striking increase in the number of lysosomes and autophagic vesicles, particularly in Type A synoviocytes, in rheumatoid synovial tissue (Lack, 1969).

From this evidence it is possible that the lysosomes of rheumatoid synoviocytes are abnormal and capable of extruding their contents on to the cartilage, to which these cells are already in close apposition. But, as Page-Thomas (1969) has remarked: 'The fibrous nature of synovial membrane and the cellular heterogeneity of the diseased tissue have deterred workers from serious biochemical studies of subcellular fractions'. Thus this was an ideal system for analysis by the techniques of quantitative cytochemistry (Bitensky et al., 1973; Bitensky and Chayen, 1977).

Cytochemical analysis of the functional state of the lysosomal membranes, based on a comparison of the free and latent activities of two intralysosomal enzymes, showed that the lysosomes of nonrheumatoid synoviocytes contained between $28 \%$ and $60 \%$ latent activity, the lower values being found in recently traiımatised joints. The total 
activity found in rheumatoid synoviocytes was at least as great, or greater, than that found in nonrheumatoid synoviocytes. But the striking finding was that not more than $5 \%$ of this activity was latent, showing that the lysosomal membranes in the rheumatoid cells were relatively functionless, at least with regard to these substrates (Chayen et al., 1971). Glucocorticoids administered to synovial tissue maintained in vitro improved the amount of latent activity up to $21 \%$. A similar improvement in latent activity was found in eight out of 13 patients who had received at least $5 \mathrm{mg}$ of prednisolone daily. It was not found in patients receiving less prednisolone (Bitensky et al., 1974b). These levels of prednisolone correlated well with the findings of Chamberlain and Keenan (1976). In a doubleblind trial patients receiving prednisolone $3 \mathrm{mg} /$ day gained little clinical benefit whereas some clinical improvement was apparent in those treated with 5 $\mathrm{mg} /$ day.

\section{Conclusion}

Since lysosomes were first described as a biochemical entity in 1955 (de Duve et al., 1955) they have been a favoured candidate for a pathogenic role in connective tissue diseases. Today it is clear that they have important functions in these diseases Their importance in intracellular metabolic processes is highlighted by the damage caused by the deletion of a single intralysosomal enzyme, as in the storage diseases. Their abundance in polymorphonuclear leucocytes and macrophages and their behaviour in response to inflammatory stimuli implicate lysosomal enzymes in acute and chronic inflammation. Such a function seems clear in gout and probably in other crystal synovitides.

There is strong evidence that extracellular lysosomal enzymes are concerned in the normal turnover of bone (Vaes, 1969) and of the extracellular components of connective tissue (Reynolds, 1969; Dingle, 1969). How much they participate in the pathogenesis of rheumatoid arthritis and osteoarthrosis still awaits full clarification. But there is strong circumstantial evidence that their part is a major if not decisive one.

\section{References}

Allison, A. C. (1968a). The role of lysosomes in the action of drugs and hormones. Advances in Chemotherapy, 3, 253-302.

Allison, A. C. (1968b). Some effects of pharmacologically active compounds on membranes. British Medical Bulletin, 24, 135-140.

Allison, A. C. (1968c). Lysosomes. In The Biological Basis of Medicine, Vol. 1, edited by E. E. Bittar and
N. Bittar, pp. 209-242. Academic Press, London.

Allison, A. C. (1971). Lysosomes and the toxicity of particulate pollutants. Archives of Internal Medicine, 128, 131-139.

Allison, A. C., Harington, J. S., and Birbeck, M. (1966). An examination of the cytotoxic effects of silica on macrophages. Journal of Experimental Medicine, 124, 141-154.

Allison, A. C., and Mallucci, L. (1964). Lysosomes in dividing cells, with special reference to lymphocytes. Lancet, 2, 1371-1373.

Allison, A. C., and Mallucci, L. (1965). Histochemical studies of lysosomes and lysosomal enzymes in virusinfected cell cultures. Journal of Experimental Medicine, 121, 463-475.

Allison, A. C., and Young, M. R. (1969). Vital staining and fiuorescence microscopy of lysosomes. In Lysosomes in Biology and Pathology, Vol. 2, edited by J. T. Dingle and H. B. Fell, pp. 600-628. North Holland, Amsterdam.

Anderson, A. J., Brocklehurst, W. E., and Willis, A. L. (1971). Evidence for the role of lysosomes in the formation of prostaglandins during carrageenininduced inflammation in the rat. Pharmacological Research Communications, 3, 13-20.

Baccino, F. M., and Zuretti, M. F. (1975). Structural equivalents of latency for lysosomal hydrolases. Biochemical Journal, 146, 97-108.

Ball, J. (1968). Post-mortem findings and articular pathology in rheumatoid arthritis. In Rheumatic Diseases, edited by J. J. R. Duthie and W. R. M. Alexander, pp. 124-126. University Press, Edinburgh.

Barnett, C. H., Davies, D. V., and MacConaill, M. M. (1961). Synovial Joints: Their Structure and Mechanics, p. 36. Longmans, London.

Barrett, A. J., and Dean, R. T. (1976). Lysosomal enzymes. In Data Book on Cell Biology, edited by P. L. Altman and D. D. Katz, pp. 317-324, Federation of American Societies for Experimental Biology, Bethesda, Maryland.

Barrett, A. J., and Heath, M. F. (1977). Lysosomal enzymes. In Lysosomes, a Laboratory Handbook, 2nd edition, edited by J. T. Dingle, pp. 19-146. North Holland, Amsterdam.

Beaufay, H. (1969). Methods for the isolation of lysosomes. In Lysosomes in Biology and Pathology, Vol. 2 , edited by J. T. Dingle and H. B. Fell, pp. 516-546. North Holland, Amsterdam.

Birkedal-Hansen, H., Cobb, C. M., Taylor, R. E., and Fullmer, H. M. (1976). Activation of fibroblast procollagenase by mast cell proteases. Biochimica et Biophysica Acta, 438, 273-286.

Bitensky, L. (1963a). Modifications to the Gomori acid phosphatase technique for controlled-temperature frozen sections. Quarterly Journal of Microscopical Science, 104, 193-196.

Bitensky, L. (1963b). The reversible activation of lysosomes on normal cells and the effects of pathological conditions. In Ciba Foundation Symposium, Lysosomes, edited by A. V.S. de Reuck and M. P. Cameron, pp. 362-375. Churchill, London.

Bitensky, L., and Chayen, J. (1977). Histochemical 
methods for the study of lysosomes. In Lysosomes, a Laboratory Handbook, 2nd edition, edited by J. T. Dingle, pp. 209-244. North Holland, Amsterdam.

Bitensky, L., and Cohen, S. (1965). The variation of endometrial acid phosphatase activity with the menstrual cycle. Journal of Obstretics and Gynaecology of the British Commonwealth, 72, 769-774.

Bitensky, L., Alaghband-Zadeh, J., and Chayen, J. (1974a). Studies on thyroid stimulating hormone and the long-acting thyroid stimulating hormone. Clinical Endocrinology, 3, 363-374.

Bitensky, L., Butcher, R. G., and Chayen, J. (1973). Quantitative cytochemistry in the study of lysosomal function. In Lysosomes in Biology and Pathology, Vol. 3, edited by J. T. Dingle, pp. 465-510. North Holland, Amsterdam.

Bitensky, L., Butcher, R. G., Johnstone, J. J., and Chayen, J. (1974b). Effect of glucocorticoids on lysosomes in synovial lining cells in human rheumatoid arthritis. Annals of the Rheumatic Diseases, 33, 57-61.

Bitensky, L., Chayen, J., Cunningham. G. J., and Fine, J. (1963). Behaviour of lysosomes in haemorrhagic shock. Nature (London), 199, 493-494.

Brady, R. O., and King, F. M. (1973). Gaucher's disease. In Lysosomes and Storage Disease, edited by $\mathrm{H}$. G. Hers and F. van Hoof, pp. 381-394. Academic Press, New York.

Burton, R., and Lloyd, J. B. (1976). Latency of some glycosidases of rat liver lysosomes. Biochemical Journal, 160, 631-638.

Cardella, C. J., Davies, P., and Allison, A. C. (1974). Immune complexes induce selective release of lysosomal hydrolases from macrophages. Nature (London), 247, 46-48.

Chalmers, R. A., Watts, R. W. E., Bitensky, L., and Chayen, J. (1969). Microscopic studies on crystals in skeletal muscle from two cases of xanthinuria. Journal of Pathology, 99, 45-56.

Chamberlain, M. A., and Keenan, J. (1976). The effect of low doses of prednisolone compared with placebo on the function and on the hypothalamic pituitary adrenal axis in patients with rheumatoid arthritis. Rheumatology and Rehabilitation, 15, 17-23.

Chayen, J., and Bitensky, L. (1971). Lysosomal enzymes and inflammation with particular reference to rheumatoid diseases. Annals of the Rheumatic Diseases, 30, 522-536.

Chayen, J., Bitensky, L., Butcher, R. G., and Cashman, B. (1971). Evidence for altered lysosomal membranes in synovial lining cells from human rheumatoid joints. Beiträge zur Pathologie, 142, 137-149.

Chayen, J., Bitensky, L., and Ubhi, G. S. (1972). The experimental modification of lysosomal dysfunction by anti-inflammatory drugs acting in vitro. Beiträge zur Pathologie, 147, 6-20.

Cohn, Z. A., and Fedorko, M. E. (1969). The formation and fate of lysosomes. In Lysosomes in Biology and Pathology, Vol. 1, edited by J. T. Dingle and H. B. Fell, pp 43-63. North Holland, Amsterdam.

Cummings, N. A., and Nordby, G. L. (1966). Measurement of synovial fluid $\mathrm{pH}$ in normal and arthritic knees. Arthritis and Rheumatism, 9, 47-56.
Daems, W. T., Wisse, E., and Brederoo, P. (1969). Electron microscopy of the vacuolar apparatus. In Lysosomes in Biology and Pathology, Vol. 1, edited by J. T. Dingle and H. B. Fell, pp. 64-112. North Holland, Amsterdam.

Davies, J. T., and Rideal, E. K. (1961). Interfacial Phenomena, p. 91. Academic Press, New York.

Dayer, J. M., Krane, S. M., Russell, R. G. G., and Robinson, D. R. (1976). Production of collagenase and prostaglandins by isolated adherent rheumatoid synovial cells. Proceedings of the National Academy of Sciences of the United States of America, 73, 945-949.

Dean, M. F. (1978). Replacement therapy in the mucopolysaccharidoses. Journal of Clinical Pathology, 31, Supplement (Royal College of Pathologists), 12, 120-127.

Dean, R. T. (1975). Direct evidence of importance of lysosomes in degradation of intracellular proteins. Nature (London), 257, 414-416.

Dean, R. T. (1977a). Lysosomes and membrane recycling. Biochemical Journal, 168, 603-605.

Dean, R. T. (1977b). Methods for the isolation of lysosomes. In Lysosomes, a Laboratory Handbook, 2nd edition, edited by J. T. Dingle, pp. 1-18. North Holland, Amsterdam.

Dean, R. T., and Barrett, A. J. (1976). Lysosomes. Essays in Biochemistry, 12, 1-40.

Desai, I. D., and Tappel, A. L. (1965). Erythrocyte hemolysis by isolated rat liver lysosomes. Proceedings of the Society for Experimental Biology and Medicine, 118, 496-499.

Dieppe, P. A., Huskisson, E. C., Crocker, P., and Willoughby, D. A. (1976). Apatite deposition disease. Lancet, 1, 266-269.

Dieppe, P. A. (1978). New knowledge of chondrocalcinosis, Journal of Clinical Pathology, 31, Supplement (Royal College of Pathologists), 12, 214-222.

Dingle, J. T. (1962). Lysosomal enzymes and the degradation of cartilage matrix. Proceedings of the Royal Society of Medicine, 55, 109-111.

Dingle, J. T. (1968). Vacuoles, vesicles and lysosomes. British Medical Bulletin, 24, 141-145.

Dingle, J. T. (1969). The extracellular secretion of lysosomal enzymes. In Lysosomes in Biology and Pathology, Vol. 2, edited by J. T. Dingle and H. B. Fell, pp. 421436. North Holland, Amsterdam.

Dingle, J. T. (1971). The immunoinhibition of cathepsin D-mediated cartilage degradation. In Tissue Proteinases, edited by A. J. Barrett and J. T. Dingle, pp. 313324. North Holland, Amsterdam.

Dingle, J. T., and Barrett, A. J. (1969). Uptake of biologically active substances by lysosomes. Proceedings of the Royal Society. Series B. Biological Sciences, 173, 85-93.

Dingle, J. T., Fell, H. B., and Glauert, A. M. (1969). Endocytosis of sugars in embryonic skeletal tissues in organ culture: IV. Lysosomal and other biochemical effects. Journal of Cell Science, 4, 139-153.

Duve, C. de (1959). Lysosomes, a new group of cytoplasmic particles. In Sub-cellular Particles, edited by T. Hayashi, pp. 128-159. Ronald Press, New York.

Duve, C. de (1969). The lysosome in retrospect. In Lysosomes in Biology and Pathology, Vol. 1, edited by 
J. T. Dingle and H. B. Fell, pp. 3-42. North Holland, Amsterdam.

Duve, C. de, Barsy, T. de, Poole, B., Trouet, A., Tulkens, P., and van Hoof, F. (1974). Lysosomotropic agents. Biochemical Pharmacology, 23, 2495-2531.

Duve, C. de, Pressman, B. C., Gianetto, R., Wattiaux, R., and Appelmans, F. (1955). Tissue fractionation studies 6. Intracellular distribution patterns of enzymes in rat liver tissue. Biochemical Journal, 60, 604-617.

Edlow, D. W., and Sheldon, W. H. (1971). The pH of inflammatory exudates. Proceedings of the Society for Experimental Medicine and Biology, 137, 1328-1332.

Eeckhout, Y., and Vaes, G. (1977). Further studies on the activation of procollagenase, the latent precursor of bone collagenase. Biochemical Journal, 166, 21-31.

Farquhar, M. G. (1969). Lysosome function in regulating secretion: disposal of secretory granules in cells of the anterior pituitary gland. In Lysosomes in Biology and Pathology, Vol. 2, edited by J. T. Dingle and H. B. Fell, pp. 462-482. North Holland, Amsterdam.

Fell, H. B., and Dingle, J. T. (1963). Studies on the mode of action of excess of Vitamin A: 6. Lysosomal protease and the degradation of cartilage matrix. Biochemical Journal, 87, 403-408.

Fell, H. B., and Thomas, L. (1960). Comparison of the effects of papain and vitamin A on cartilage: II. The effects on organ cultures of embryonic skeletal tissue. Journal of Experimental Medicine, 111, 719-744.

Galdston, M., Janoff, A., and Davis, A. L. (1973). Familial variation of leukocyte lysosomal protease and serum $a_{1}$-antitrypsin as determinants in chronic obstructive pulmonary disease. American Review of Respiratory Diseases, 107, 718-727.

Ghadially, F. N., and Roy, S. (1967). Ultrastructure of synovial membrane in rheumatoid arthritis. Annals of the Rheumatic Diseases, 26, 426-443.

Glynn, L. E. (1977). Primary lesion in osteoarthrosis. Lancet, 1, 574-575.

Goldman, S. S. (1976). Ion distribution and membrane permeability in lysosomal suspensions. In Lysosomes in Biology and Pathology, Vol. 5, edited by J. T. Dingle and R. T. Dean, pp. 309-336. North Holland, Amsterdam.

Goldstein, I. M. (1974). Lysosomal hydrolases and inflammatory materials. In Mediators of Inflammation, edited by G. Weissmann, pp. 51-84. Plenum Press, New York.

Goldstein, I. M., and Weissmann, G. (1974). Generation of C5-derived lysosomal enzyme-releasing activity (C5a) by lysates of leukocyte lysosomes. Journal of Immunology, 113, 1583-1588.

Henson, P. (1971). Interaction of cells with immune complexes: adherence, release of constituents, and tissue injury. Journal of Experimental Medicine, 134, $114 \mathrm{~S}-135 \mathrm{~S}$.

Hers, H. G. (1973). The concept of inborn lysosomal disease. In Lysosomes and Storage Diseases, edited by H. G. Hers and F. van Hoof, pp. 148-172. Academic Press, New York.

Hers, H. G., and Barsy, T. de (1973). Type II glycogenosis (acid maltase deficiency). In Lysosomes and Storage Diseases, edited by H. G. Hers and F. van Hoof, pp. 197-217. Academic Press, New York.
Hers, H. G., and Hoof, F. van. (1973). Editors, Lysosomes and Storage Diseases. Academic Press, New York.

Hollander, J. L., McCarty, D. J., Jr., Astorga, G., and Castro-Murillo, E.(1965). Studies on the pathogenesis of rheumatoid joint inflammation: 1 . The R.A. cell and a working hypothesis. Annals of Internal Medicine, 62, 271-280.

Holt, S. J. (1959). Factors governing the validity of staining methods for enzymes, and their bearing upon the Gomori acid phosphatase technique. Experimental Cell Research, Suppl., 7, 1-27.

Hopsu-Havu, V. K., Mäkinen, K. K., and Glenner, G. G. (1966). Formation of bradykinin from Kallidin-10 by aminopeptidase B. Nature (London), 212, 1271-1272.

Hösli, P., and Vogt, E. (1977). Cystic fibrosis: leakage of lysosomal enzymes and of alkaline phosphatase into the extracellular space. Biochemical and Biophysical Research Communications, 79, 741-748.

Janoff, A., and Zweifach, B. W. (1964). Production of inflammatory changes in microcirculation by cationic proteins extracted from lysosomes. Journal of Experimental Medicine, 120, 747-764.

Kantrowitz, F., Robinson, D. R., McGuire, M. B., and Levine, L. (1975). Corticosteroids inhibit prostaglandin production by rheumatoid synovia. Nature (London), 258, 737-739.

Koenig, H. (1969). Lysosomes in the nervous system. In Lysosomes in Biology and Pathology, Vol. 2, edited by J. T. Dingle and H. B. Fell, pp. 111-162. North Holland, Amsterdam.

Koenig, H. (1974). The soluble acidic lipoproteins (SALPS) of storage granules. Matrix constituents which may bind molecules. In Cytopharmacology of Secretion. (Advances in Cytopharmacology, Vol. 2), edited by B. Ceccarelli, F. Clementi, and J. Meldolesi, pp. 273-301. Raven Press, New York.

La Badie, J., Dunn, W. A., and Aronson, N. N. (1976). Hepatic synthesis of carnitine from protein-bound trimethyl-lysine. Biochemical Journal, 160, 85-95.

Lack, C. H. (1969). Lysosomes in relation to arthritis. In Lysosomes in Biology and Pathology, Vol. 1, edited by J. T. Dingle and H. B. Fell, pp. 493-508. North Holland, Amsterdam.

Lack, C. H., and Ali, S. Y. (1964). Tissue activator of plasminogen. Nature (London), 201, 1030-1031.

Lane, N. J. (1968). Lipochondria, neutral red granules and lysosomes: synonymous terms? In Cell Structure and Its Interpretation, edited by S. M. McGee-Russell and K. F. A. Ross, pp. 169-182. Arnold, London.

Lucy, J. A. (1969). Lysosomal membranes. In Lysosomes in Biology and Pathology, Vol. 2, edited by J. T. Dingle and H. B. Fell, pp. 312-341. North Holland, Amsterdam.

Lucy, J. A. (1970). The fusion of biological membranes. Nature (London), 227, 815-817.

Lucy, J. A., and Lichti, F. U. (1969). Reactions of vitamin $A$ with acceptors of electrons. Interactions with iodine and the formation of iodide. Biochemical Journal, 112, 231-241.

McCarty, D. J. (1968). On the trail of a crystal. In Vistas 
in Connective Tissue Diseases, edited by J. C. Bennett, pp. 194-202. Thomas, Springfield, Illinois.

McLaren, A. D., and Packer, L. (1970). Some aspects of enzyme reactions in heterogenous systems. Advances in Enzymology and Related Subjects of Biochemistry, 33, 245-308.

Mego, J. L. (1973). A biochemical method for the evaluation of heterolysosome formation and function. In Lysosomes in Biology and Pathology, Vol. 3, edited by J. T. Dingle, pp. 527-538, North Holland, Amsterdam.

Misch, D. W., and Misch, M. S. (1975). The effects of dimethylsulphoxide on a lysosomal membrane. Annals of the New York Academy of Sciences, 243, 54-59.

Movat, H. Z., Uriuhara, T., Macmorine, D. L., and Burke, J. S. (1964). A permeability factor released from leucocytes after phagocytosis of immune complexes and its possible role in the Arthus reaction. Life Sciences, 3, 1025-1032.

Muirden, K. D. (1972). Lysosomal enzymes in synovial membrane in rheumatoid arthritis. Relationship to joint damage. Annals of the Rheumatic Diseases, 31, 265-271.

Munro, T. R., Daniel, M. R., and Dingle, J. T. (1964). Lysosomes in Chinese hamster fibroblasts in culture. Experimental Cell Research, 35, 515-530.

O'Brien, J. S. (1973). Tay-Sachs' disease and juvenile $\mathrm{G}_{\mathrm{M}_{2}}$-gangliosidosis. In Lysosomes and Storage Diseases, edited by H. G. Hers and F. van Hoof, pp. 323-345. Academic Press, New York.

Page-Thomas, D. P. (1969). Lysosomal enzymes in experimental and rheumatoid arthritis. In Lysosomes in Biology and Pathology, Vol. 2, edited by J. T. Dingle and H. B. Fell, pp. 87-110. North Holland, Amsterdam.

Peters, T. J., Heath, J. R., Wansbrough-Jones, M. H., and Doe, W. F. (1975). Enzyme activities and properties of lysosomes and brush borders in jejunal biopsies from control subjects and patients with coeliac disease. Clinical Science and Molecular Medicine, 48, 259-267.

Peters, T. J., and Seymour, C. A. (1976). Acid hydrolase activities and lysosomal integrity in liver biopsies from patients with iron overload. Clinical Science and Molecular Medicine, 50, 75-78.

Phelps, P., and McCarty, D. J., Jr. (1966). Crystal-induced inflammation in canine joints: II. The importance of polymorphonuclear leukocytes. Journal of Experimental Medicine, 124, 115-126.

Quarles, R. H., and Dawson, R. M. C. (1969). A shift in the optimum $\mathrm{pH}$ of phospholipase $\mathrm{D}$ produced by activating long-chain anions. Biochemical Journal, 112, 795-799.

Rawson, A. J., Abelson, N. M., and Hollander, J. L. (1965). Studies on the pathogenesis of rheumatoid joint inflammation: II. Intracytoplasmic particulate complexes in rheumatoid synovial fluids. Annals of Internal Medicine, 62, 281-284.

Reijngoud, D. J., and Tager, J. M. (1973). Measurement of intralysosomal pH. Biochimica et Biophysica Acta, 297, 174-178.

Restifo, R. A., Lussier, A. J., Rawson, A. J., Rockey, J. H., and Hollander, J. L. (1965). Studies on the pathogenesis of rheumatoid joint inflammation: III. The experimental production of arthritis by the intraarticular injection of purified 7S gamma globulin. Annals of Internal Medicine, 62, 285-291.

Reynolds, J. J. (1969). Connective tissue catabolism and the role of lysosomal enzymes. In Lysosomes in Biology and Pathology, Vol. 2, edited by J. T. Dingle and H. B. Fell, pp. 163-177. North Holland, Amsterdam.

Reynolds, J. J., Murphy, G., Sellers, A., and Cartwright, E. (1977). A new factor that may control collagen resorption. Lancet, 2, 333-335.

Robbins, E., and Marcus, P. I. (1963). Dynamics of acridine orange-cell interaction. 1. Inter-relationships of acridine orange particles and cytoplasmic reddening. Journal of Cell Biology, 18, 237-250.

Robinson, D. R., Tashjian, A. H., Jr., and Levine, L. (1975). Prostaglandin-stimulated bone resorption by rheumatoid synovia. Journal of Clinical Investigation, 56, 1181-1188.

Schellens, J. P. M., Daems, W. Th., Emeis, J. J., Brederoo, P., Bruin, W. C. de, and Wisse, E. (1977). Electron microscopical identification of lysosomes. In I Lysosomes, a Laboratory Handbook, 2nd edition, edited by J. T. Dingle, pp. 147-208. North Holland, Amsterdam.

Schorlemmer, H. U., and Allison, A. C. (1976). Effects of activated complement components on enzyme secretion by macrophages. Immunology, 31, 781-788.

Schorlemmer, H. U., Bitter-Suermann, D., and Allison, A. C. (1977). Complement activation by the alternative pathway and macrophage enzyme secretion in the pathogenesis of chronic inflammation. Immunology, 32, 929-940.

Schorlemmer, H. U., Davies, P., and Allison, A. C. (1976). Ability of activated complement components to induce lysosomal enzyme release from macrophages. Nature (London), 261, 48-49.

Scott, J. T. (1978). New knowledge of the pathogenesis of gout. Journal of Clinical Pathology, 31, Supplement (Royal College of Pathologists), 12, 205-213.

Seegmiller, J. E., and Howell, R. R. (1962). The old and new concepts of acute gouty arthritis. Arthritis and Rheumatism, 5, 616-623.

Sellers, A., Cartwright, E., Murphy, G., and Reynolds, J. J. (1977). Evidence that latent collagenases are enzyme-inhibitor complexes. Biochemical Journal, 163, 303-307.

Small, J. (1954). Modern Aspects of $p H$. Baillière, Tindall and Cox, London.

Uhr, J. W. (1964). Heterogeneity of the immune response. Science, 145, 457-464.

Uriuhara, T., Macmorine, D. R. L. and Franklin, A. E. (1965). The pathogenicity of PMN-leukocyte lysosomes in allergic inflammation and tissue injury. Federation Proceedings, 24, 368.

Vaes, G. (1969). Lysosomes and the cellular physiology of bone resorption. In Lysosomes in Biology and Pathology, Vol. 1, edited by J. T. Dingle and H. B. Fell, pp. 217-253. North Holland, Amsterdam.

Vaes, G. (1972). The release of collagenase as an inactive proenzyme by bone explants in culture. Biochemical Journal, 126, 275-289. 
Watts, R. W. E., Scott, J. T., Chalmers, R. A., Bitensky, L., and Chayen, J. (1971). Microscopic studies on skeletal muscle in gout patients treated with allopurinol. Quarterly Journal of Medicine, 40, 1-14.

Weber, R. (1969). Tissue involution and lysosomal enzymes during anuran metamorphosis. In Lysosomes in Biology and Pathology, Vol. 2, edited by J. T. Dingle and H. B. Fell, pp. 437-461. North Holland, Amsterdam.

Weissmann, G. (1964). Lysosomes, autoimmune phenomena and diseases of connective tissue. Lancet, 2, 1373-1375.

Weissmann, G. (1966). Lysosomes and joint disease. Arthritis and Rheumatism, 9, 834-840.

Weissmann, G. (1967). Structure and function of lysosomes. Rheumatology, 1, 1-27.

Weissmann, G. (1968). Effect on lysosomes of drugs useful in connective tissue disease. A Symposium on the Interaction of Drugs and Subcellular Components in Animal Cells, edited by P. N. Campbell, pp. 203-212. Churchill, London.

Weissmann, G. (1969). The effects of steroids and drugs on lysosomes. In Lysosomes in Biology and Pathology, Vol. 1, edited by J. T. Dingle and H. B. Fell, pp. 276298. North Holland, Amsterdam.

Weissmann, G., Dukor, P., and Zurier, R. B. (1971a). Effect of cyclic AMP on release of lysosomal enzymes from phagocytes. Nature New Biology (London), 231,
131-135.

Weissmann, G., Spilberg, I., and Krakauer, K. (1969). Arthritis induced in rabbits by lysates of granulocyte lysosomes. Arthritis and Rheumatism, 12, 103-116.

Weissmann, G., Zurier, R. B., Spieler, P. J., and Goldstein, I. M. (1971b). Mechanisms of lysosomal enzyme release from leukocytes exposed to immune complexes and other particles. Journal of Experimental Medicine, 134, 149S-164S.

Weston, P. D., and Poole, A. R. (1973). Antibodies to enzymes and their uses, with specific reference to cathepsin D and other lysosomal enzymes. In Lysosomes in Biology and Pathology, Vol. 3, edited by J. T. Dingle, pp. 425-464. North Holland, Amsterdam.

Woessner, J. F. (1973). Purification of cathepsin D from cartilage and uterus and its action on the proteinpolysaccharide complex of cartilage. Journal of Biological Chemistry, 248, 1634-1642.

Woessner, J. F. (1977). A latent form of collagenase in the involuting rat uterus and its activation by a serine proteinase. Biochemical Journal, 161, 535-542.

Zucker-Franklin, D., and Hirsch, J. G. (1964). Electron microscope studies on the degranulation of rabbit peritoneal leukocytes during phagocytosis. Journal of Experimental Medicine, 120, 569-576.

Zurier, R. B. (1974). Prostaglandins. In Mediators of Inflammation, edited by G. Weissmann, pp. 163-180. Plenum Press, New York. 